\title{
Sacred Buddha Image: The Integration of Indigenous Knowledge on Traditions, Rituals, and Beliefs for Developing Cultural Tourism of Communities in Isan Region
}

\author{
Chanakan Wisetphai ${ }^{1}$, Somchai Lamduan ${ }^{1} \&$ Sitthisak Champadaeng ${ }^{1}$ \\ ${ }^{1}$ Faculty of Cultural Science, Mahasarakham University, Muang District, Maha Sarakham, Thailand \\ Correspondence: Chanakan Wisetphai, Faculty of Cultural Science, Mahasarakham University, Muang District, \\ Maha Sarakham 44000, Thailand. E-mail: tooktanaja12@hotmail.com
}

Received: April 19, 2014 Accepted: June 6, 2014 Online Published: June 26, 2014

doi:10.5539/ach.v6n2p235 URL: http://dx.doi.org/10.5539/ach.v6n2p235

\begin{abstract}
Sacred Buddha Image is a symbolic culture of the Buddha or the great founder of Buddhism highly praised by Buddhists. Each sacred Buddha image was created from the faith in the Buddha of the head builder, the joint builders, and the sculptor. Most sacred Buddha images in Isan region (northeast Thailand) were built during 637-1817 A.D. and monasteries were also built in the same period. People believe in the sacred power of these period. People believe in them luck, and prosperity. This research reflects the background of some sacred Buddha images and the use of them for promoting cultural tourism, including current situations and difficulties of the use of them as cultural capital for promoting cultural tourism. Research areas consisted of the provinces of Nakhon Phanom, Amnat Charoen, and Ubon Ratchathani where the sacred Buddha images located in.
\end{abstract}

Keywords: Sacred Buddha image, Integration, indigenous knowledge, cultural tourism, Isan region

\section{Introduction}

King Asoka, The Great is the third king of the Moriya Dynasty of India, he reigned during 270-311 B.E. and built a lot of monasteries but Buddha statues were not built in that period. For 500 years after the Buddha died, the first Buddha statues were built by people believing in his doctrine, they were influenced by artistic styles of Kreek and Roman. These statues were built for representing a symbol of the Buddha's virtue so they were not portraits of him (The Fine Arts Department, 2002)

Buddhism was introduced into Thailand about twenty-three centuries ago when the region was still populated by Mons and Lawas. Nakhon Pathom was then the administrative center and after the advent of the religion, became an active seat of Buddhist propagation. Later on the region was occupied by the Thais, also followers of Buddhism; Khun Luang Mao, who ruled over the Ailao Kingdom about two thousand years ago, was the first Thai Buddhist king and the professed upholder of the religion (Phramaha Somphong Santacitto, 2010).

Isan people (people living in northeast Thailand) tend to create Buddha images from wood into many sizes. The Buddha images housed in temples, viharas, and other religious buildings are sculptural works of skilled craft men of northeast Thailand. People living in village where has a project of Buddha image creation, they will participate in a money-donation for it and when it is already made, they will hold a celebration with some types of entertainment such as bands of northeastern folksingers, east northern folk plays, or others. A period of celebration may be held for nine nights and nine days or over, it is a period of happiness of all people (Suwich Sathitwittayanan, 1991).

There are a lot of sacred things in Isan (northeast Thailand) region such as relics of the Buddha, chedis stupas containing relics of the Buddha, and ancient sacred Buddha images. These sacred things have their historical value and general people believe in their sacred power so the monastery in which the sacred Buddha image housed, it will become a tourist attraction and many people make merit there such as offering food to monks, doing a ritual of bathing a sacred Buddha image, and other Buddhist rituals. When people encounter with some problems, they usually ask a sacred Buddha image for helping them to defeat the problems. After they can defeat them, they will make votive offerings to the sacred Buddha image in accordance with a promise of each one; for example, if someone makes a promise with a sacred Buddha image that he or she will perform a Thai dance in the presence of it, he or she must strictly perform (Thotsaphon Changphanichkun, 2009). 
Since Thailand has a lot of cultural tourism resources, sacred Buddha images can be used as a kind of cultural resources for promoting cultural tourism. Buddhist way is a main way of life of Thai people so this cultural identity can be integrated into tourism strategy of organizations concerned. Both Thai and foreign tourists are a target group because Buddhist way is familiar with a majority of Thai people and it is an attractive way for foreigners. Cultural diversity is an important point of each country, it benefits all sectors of tourism. Thus, developing cultural resources is necessary for tourism promotion (Photchana Bunkhum, 2007)

\section{Research Purposes}

1) To investigate the background of sacred Buddha images which are related to indigenous knowledge on traditions, rituals, and beliefs in Isan region.

2) To investigate current situations and difficulties of the use of indigenous knowledge on traditions, rituals, and beliefs in sacred Buddha images for cultural tourism of communities in Isan region.

3) To investigate the integration of indigenous knowledge on traditions, rituals, and beliefs in sacred Buddha images for developing cultural tourism of communities in Isan region

\section{Research Methodology}

A qualitative research was used for this research. Research areas were these: 1) Nakhon Phanom Province, the sacred Buddha images were Phra Tiew and Phra Thiam housed in Wat Okar (Okat temple), Nai Mueang Sub-District, Mueang District and Phra Bang housed in Wat Trai Phum (Trai Phum temple), Tha Uthen Sub-District, Tha Uthen District; 2) Amnat Charoen Province, the sacred Buddha images were Phra Lao Thepnimit housed in Wat Phra Lao Thepnimit (Phra Lao Thepnimit temple), Phana Sub-District, Phana District, and Phra Chao Yai Lue Chai housed in Wat Amnat, Lue Amnat Sub-District, Lue Amnat District; and 3) Ubon Ratchathani Province, the sacred Buddha images were Phra Chao Yai In Plaeng housed in Wat Maha Wana Ram (Maha Wana Ram temple), Nai Mueang Sub-District, Mueang District, and Phra Chao Yai Ong Tue housed in Wat Phra Toe, Phra Lan Sub-District, Natan District.

Research instruments were a primary survey, an observation, an interview, and a focus group discussion. A sample of 78 people consisted of 24 key informants, 30 casual informants, an 24 general informants.

A triangulation technique was used for examining research data. The data were analyzed according to research purposes and research results were presented by means of a descriptive analysis

\section{Results}

The background of sacred Buddha images which are related to indigenous knowledge on traditions, rituals and beliefs in Isan region. It has revealed that almost all of sacred Buddha images in Isan region (northeast Thailand) were sculpted during 647-1907 and monasteries were built in the same period. When each village had its strength of economy, all villagers tended to cooperate in the construction of village's monastery and a sacred Buddha image of the temple. Afterwards, they practiced traditions, rituals according to their beliefs in the marvelous power of the sacred Buddha image.

Current situations and difficulties of the use of indigenous knowledge on traditions, rituals and beliefs in sacred Buddha images for developing cultural tourism of communities in Isan region. It has revealed that traditions and rituals related to the sacred Buddha image of each community are different, they depend on the beliefs in the marvelous power of the sacred Buddha image of each community. And the persons who concern in holding Buddhist activities are monks, Brahmans, and community people. Difficulties are lack of descendants' who understand the use of indigenous knowledge for carrying on traditions and rituals, lack of facilities used for servicing tourists and participants, and lack of learning centers of indigenous knowledge for transmitting knowledge to youths, children, and general people, including lack of key persons who transmit indigenous knowledge, traditions, rituals concerned to students and general people,

The intergration of indigenous knowledge on traditions, rituals and beliefs in sacred Buddha images for developing cultural of communities in Isan region has revealed that people, monks, Brahmans, state sector, and private sector cooperate in using this knowledge for developing cultural tourism in many terms such as establishing community museum as an exhibition and learning center of the knowledge concerning the Buddha image and history of community, providing tourists and participants with facilities such as accommodation in the form of home stays, public toilets, food shops, retail shops, souvenir shops, parking lots, and village security.

\section{Discussion}

As for the background of each sacred Buddha image housed in each monastery in the research area has shown that the newest one of all sacred Buddha images is Phra Chao Yai Lue Chai at Wat Amnat, Lue Amnat District, 
Amnat Charoen Province, its age is 159 years. And the oldest one of all is Pra Chao Ong Tue at Wat Phra To, Na Tan District, Ubon Ratchathani Province, its age is 1,377 years. The people believing in the sanctity of sacred Buddha image thinks that the Buddha images can give luck, security, recovery, accidental safety, prosperity, a son or a daughter and a position for the people who worships and asks it. Since all sacred Buddha images were sculpted during 637-1817 A.D., Sculptural styles of them are different and depend on the popular style of each period, including an artisan or a group of artisans who sculpted them is also different in artistic skills. Each Buddha image was made by close cooperation of monks, villagers and all Buddhists concerned in order to appreciate his virtue of the Buddha and perpetuate Buddhism forever and ever. This is consistent with a research results of Phra Sirodome Wachirawaraphorn (2010), his research entitled Reclining Buddha Images and Developing Learning Sources by Community Participation in Central Region, it has indicated that the background of reclining Buddha images in central region are not clear in terms of which period they sculpted but it is sure that they were sculpted from the belief in Buddhism of Thai Buddhists in order to perpetuate Buddhism for a long time to come. And it is also consistent with a research result of Wiraphon Phuwanon (2002), the result has indicated that in case of the Buddha statues called Luang Phor Song Phi Nong which were excavated at Ban Pa Kha, Si Bun Rueang District, Nong Bua Lamphu Province by a group of hunters in 1932 and a Buddhist monk called Phra Phorn Siangwan and Buddhists of Ban Nong Khiat, Chumphae District, Khon Kaen Province asked them for housing the two Buddha statues at Wat Sila Chod (Sila Chod monastery) in 1933 and finally these Buddha statues were moved to a new monastery called Wat Mai Samakki (Mai Samakki monastery) in 1953 by unanimous opinion of all persons concerned. It can say that the sacred Buddha statues as mentioned above have their marvelous backgrounds and ages.

Current situations of the use of indigenous knowledge on traditions, rituals and beliefs in sacred Buddha images for developing cultural tourism of communities in Isan region have revealed that people who concern with tradition and ritual practice relating to the beliefs in sacred Buddha images are monks, Brahmans, and community people. The first day of a tradition or a ritual always begins on a period of waxing moon of the third month, the fifth month or the sixth month of the lunar calendar every year. Indigenous knowledge used for gathering people to participate in religious activities is a marvelous story concerning a sacred Buddha image of each community. Generally, religious activities consist of offering food to monks, gilding the sacred Buddha image bathing the sacred Buddha image, blessing the sacred Buddha image for good luck, making meditation, and praying from the night till the dawn. Moreover, each monastery tends to provide some entertainments for entertaining participants such as folk singers' performance, Muay Thai (Thai boxing), movie, and folk plays. Details of a religious activity of each monastery may be different but the same goal is for worshipping sacred Buddha image and encouraging people and tourists to participate in monastery's activity. This is consistent with a research result of Suphot Thongnueakhaow (1995), he studied about the belief in Phra That Kham Kaen (Kham Kaen stupa), Ban Kham Sub-District, Nam Phong District, Khon Kaen Province, it has revealed that rituals are practiced by the cooperation of monks, Brahmans, and people in order to worship Phra Thai Kham Kaen that they believe in its marvelous effects, especially it protects them from perils and brings them lots of luck.

Current difficulties of the use of indigenous knowledge on traditions, rituals, and beliefs in sacred Buddha images for developing cultural tourism of communities in Isan region have revealed that the main difficulties are lack of descendants who understand the use of indigenous knowledge carrying on traditions and rituals, lack of facilities used for carrying on traditions and rituals, lack of facilities used for servicing tourists and participants, lack of rest places and accommodation for participants and tourists, lack of learning centers of indigenous knowledge used for transmitting this knowledge to youths, children, and general people, and lack of key persons who transmit indigenous knowledge on traditions, rituals, and beliefs in sacred Buddha imaged to younger generation. In terms of lack of accommodation and facilities used for servicing tourists and participants, it is consistent with a research result of Panomporn Sansittiyot (2009), the research entitled Phuthai: The Ways to Manage Cultural Villages (Home Stay) for Tourism in Mukdahan Province, it has indicted that accommodation in the form of home stays are not sufficient for tourists in case of a large number of them come to the target village, some foreign tourists cannot eat some kinds of native food, some of them do not understand some parts of native culture, and sometimes products or souvenirs of villages are not sufficient for a demand of tourists, This is also consistent with a research result of Phra Khru Suttawisutthikhun Phad (2009), the finding has indicated that people believe in marvelous power of Phra Buddha Sothorn for bringing good luck, some make a votive offering and others in accordance with one's belief so the monastery must provide them with sufficient facilities such as parking lots, public bathrooms and toilets, things for worshipping, sacred things concerned, and other needs for people who come to worship Phra Buddha Sothorn. 
The integration of indigenous knowledge on traditions, rituals, and beliefs in sacred Buddha images for developing cultural tourism of communities in Isan region has revealed that all sectors of communities cooperate in cultural tourism promotion. The knowledge concerning sacred Buddha image and its marvelous power, including the history of each community is recorded systematically and it is used as a main theme for tourism promotion. Each monastery and community cooperates in setting a strategic plan for developing cultural tourism in its area and then holds tourism activities according to the plan; for example informing tourists and general people about a cultural tourism route in its community and reighboring communities through leaflets, brochures, and a website handled by a

Tourist-information center of community, establishing a museum and learning center in a monastery where a sacred Buddha image is housed in order to educate general people and tourists about the backgrounds of sacred Buddha image, accommodation or rest places for tourists and participants who participate in religious activities of community throughout the year by the cooperation of monastery, a community, neighboring hotels, and guesthouses, providing camping areas for tourists and participants during a monastery's festival, providing facilities such as public toilets and bathrooms, parking lots, retail shops, souvenir shop, and community's security. This is consistent with a research result of Wansad Srisuwan (2010), the research entitled Model of Cultural Tourism Management Through the Participation of Tapee River Basin Communities, it has indicate that all sectors in the Tapee River Basin Communitites cooperate in developing cultural tourism efficiently. It is also consistent with a research result of Photchana Chatchawan (2008), the research has indicated that two groups who cooperate in cultural tourism management are the group of government officials and community people. Both groups work together like a network of relatives, the group of government officials determines the tourism policy and plan, supports on community products, transmits knowledge on planning, allots budgets, develops readiness of the tourism areas, and maintains and promotes participation of local people, the group of community people set 3 stages or tourism management are these: 1) preparation stage consisted of primary data collection, introduction tourist attractions, and opening for guide tour applications, 2) operational stage consisted of cleaning, arranging, adjusting, decorating, maintaining and keeping tourist attractions, and 3) summarizing stage consisted of holding a meeting between local organizations and community people for setting up guidelines for operation.

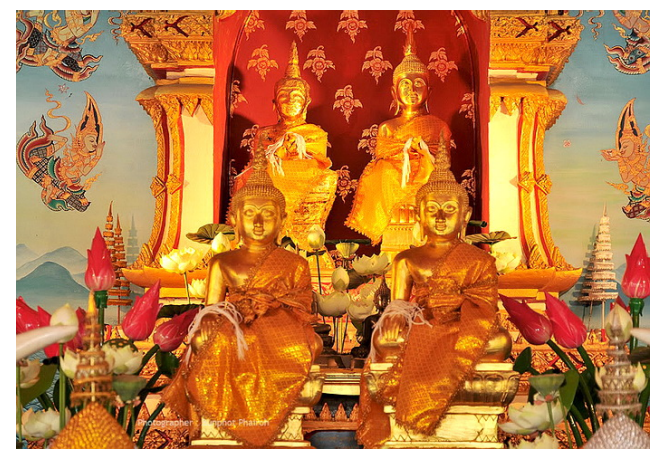

Figure 1. The sacred Buddha images called Phra Tiw and Phra Thiam housed at Wat Okat (Okat Temple), Nai Mueang Sub-District, Mueng District, Nakhon Phanom Province

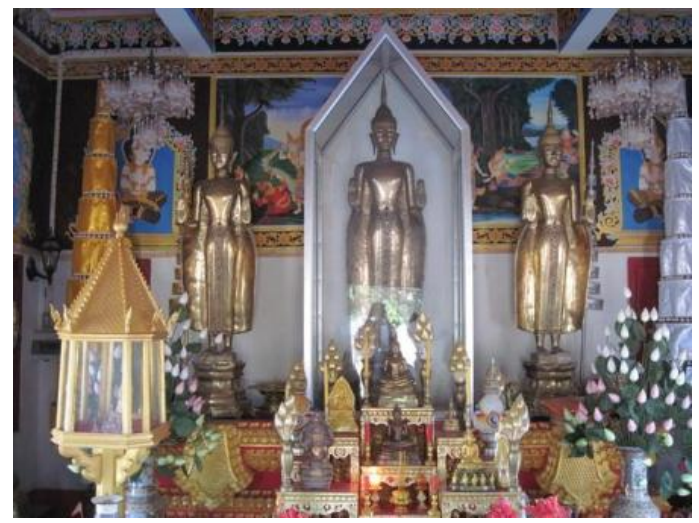

Figure 2. The sacred Buddha images called Phra Bang housed at Wat Tri Phum (Tri Phum Temple), Tha Uthen District, Nakhon Pranom Province 


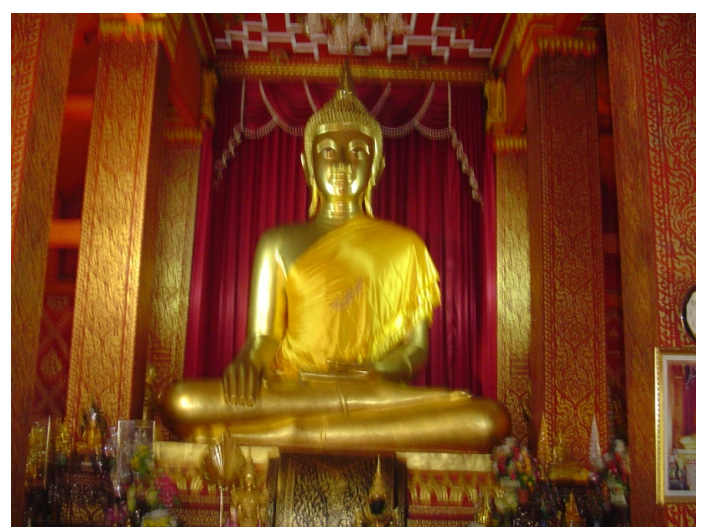

Figure 3. The sacred Buddha images called Phra Lao Thep Nimit housed at Wat Phra Lao Thep Nimit, Phana Sub-District Phana District, Amnat Charoen Province

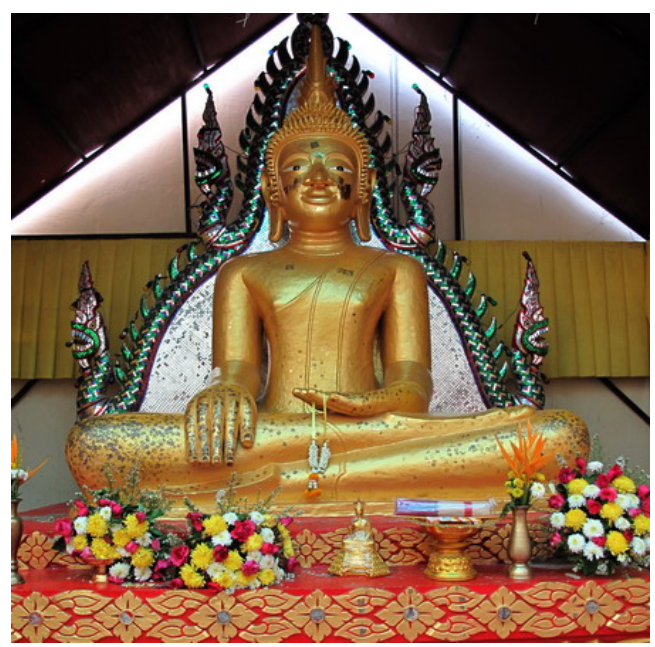

Figure 4. The sacred Buddha images called Phra Cho Yai Lue Chai housed at Wat Ban Amnat, Lue Amnat District, Amnat Charoen Province

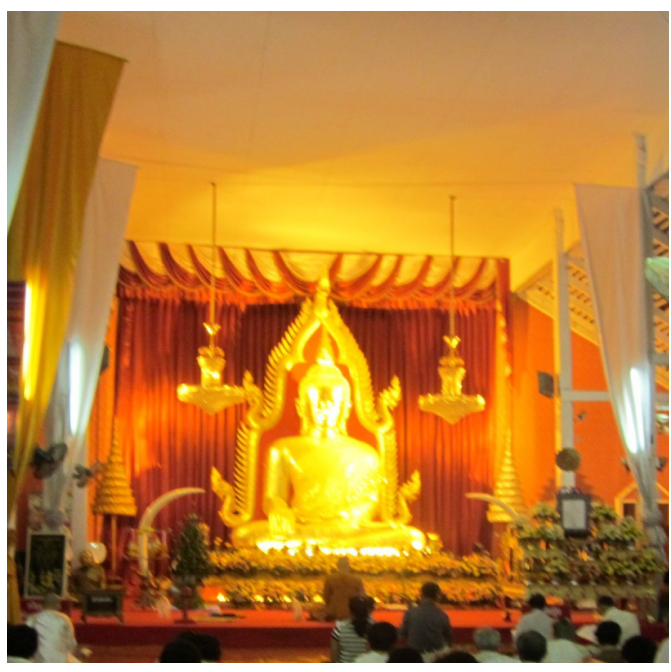

Figure 5. The sacred Buddha images called Phra Cho Yai in Plang housed at Wat Maha Wana Ram, Nai Mueang Sub-District, Mueang District, Ubon Ratchathani Province 


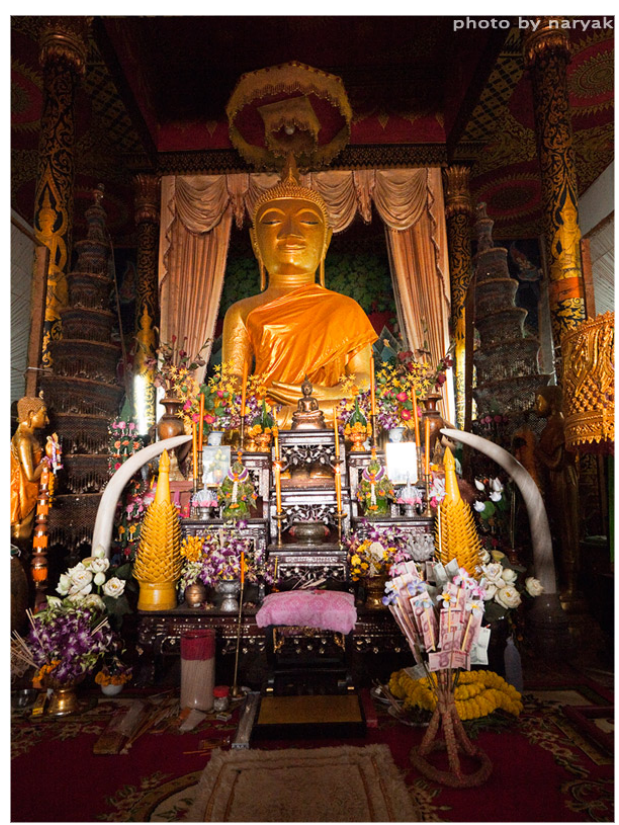

Figure 6. The sacred Buddha images called Phra Cho Yai Ong Tue housed at Wat Phra Toe, Phra Lan Sub-District, Na Tan District, Ubon Ratchathani Province

\section{Conclusion}

The integration of indigenous knowledge on traditions, rituals, and beliefs in sacred Buddha images for developing cultural tourism of communities in Isan region reflects cooperation of all sectors concerned. The belief in sacred Buddha image of people of each community significantly affects the cooperation in developing cultural tourism. Indigenous knowledge on traditions and rituals relating to sacred Buddha image should be transmitted to next generations because this is the best way to perpetuate social cooperation and social solidarity. All Buddhist communities can adapt some ideas from this research to develop cultural tourism.

\section{References}

Bhad, S. P. K. (2009). The Appropriate Forms of Managing Wat Sothorn Wararam Wora Wiharn in Developing the Socio-Economic and Cultural Aspects Based on People's Beliefs and Religious Ceremonies Pertaining to the Venerable Image, Luangpor Buddha Sothorn. Doctoral Thesis. Maha Sarakham: Mahasarakham University.

Changphanichkun, T. H. (2009). Sacred Things of Northeastern Cities (Isan). Bangkok: Comma.

Chatchawan, P. H. (2008). Cultural Tourism Management in Amphoe Khum Muang, Changwat Kalasin. Master Degree's Thesis. Maha Sarakham: Mahasarakham University.

Phuwanon, W. (2002). Beliefs and Rituals Concerning Buddha Statues Called Luang Phor Song Phi Nong: A Case Study of Ban Nong Khiat, Amphoe Chumphae, Changwat Khon Kaen. Master Degree's Thesis. Loei: Loei Rajabhat University.

Santacitto, S. Phramaha. (2010). Take Me to the Temple. Bangkok: Buddhist Sangha Youth Thailand.

Sarnsittiyot, P. (2009). Phuthai: The Ways to Manage Cultural Villages for Tourism (Home Stay) in Changwat Mukdahan. Master Degree's Thesis. Maha Sarakham: Mahasarakham University.

Sathitwittayanan, S. (1991). Wooden Buddha Images in Khon Kaen Province. Isan Journal of Buddhism, 10(1), 46.

Srisuwan, W. (2010). Model of Cultural Tourism Management through the Participation of Tapee River Basin Communities. Doctoral Thesis. Maha Sarakham: Mahasarakham University.

The Fine Arts Department. (2002). Important Buddha Images. Bangkok: Fine Arts Department Press.

Thongnueakhaow, S. (1995). A Study of The Belief in Phra That Kham Kaen, Ban Kham Sub-District, Nam Phong District, Khon Kaen Province. Master Degree's Thesis. Maha Sarakham: Mahasarakham University. 
Wachirawaraphorn, S. P. (2010). The Reclining Buddha Statule and the Development of Learning Center Through Community Participation in Central Thailand. Master Degree's Thesis. Maha Sarakham: Mahasarakham University.

\section{Copyrights}

Copyright for this article is retained by the author(s), with first publication rights granted to the journal.

This is an open-access article distributed under the terms and conditions of the Creative Commons Attribution license (http://creativecommons.org/licenses/by/3.0/). 